\title{
Christians in Iraq An analysis of some recent political developments
}

\author{
Herman G.B. Teule \\ Catholic University Leuven, Radboud University Nijmegen
}

\begin{abstract}
The collapse of the Saddam regime in March 2003 saw the publication of a number of articles or more encompassing works devoted to the situation of the Christian communities in Iraq. ${ }^{1}$ The majority of these focus on ecclesiastical issues and much less on political developments. However, it is clear that it would be artificial to separate the religious from the political: some religious leaders actively participate in the political debate and express views on the ethnic profile of their community, which has consequences for the role they want their communities to play in the Iraqi society.

The present article tries to describe and understand some political developments, focusing on three interrelated themes: the divided political landscape, the position of the Christians in Kurdistan and their relations with the Kurdish Regional Government and the Central Federal Government and the discussion on political and cultural "autonomy" for the Christian communities and the creation of a Christian "homeland".
\end{abstract}

l) O'Mahony (2004a); O'Mahony (2004b); 0'Mahony (2006), esp. 532-532; Rassam (2006); Suermann (2006); Teule (2008); Teule (2009); Audo (2008); Winkler (2009); Galletti (2010); Healy (2010); Suermann (2010); Yacoub (2008); Yacoub (2010).

Several data in this article are based on information acquired during two visits to Northern Iraq and the Plain of Nineveh (July, 2008, May, 2010) as well as on interviews with Chaldo-Syrian-Assyrian politicians in the diaspora. It is not possible to mention the names of my informants, whom I would like to thank for their patience and willingness to answer my questions. 


\section{The divided political landscape}

Traditionally, Christians in the Middle East define themselves in the first place according to religious affiliation. This is due to the system inherited from the Ottoman times, where the leaders of the religious communities, as head of the millet, to a certain extent were considered as representing their people on the national political and societal level. The proliferation of millets in the $19^{\text {th }}$ century, when each religious denomination became its own millet, and consequently, each head of a particular Church was given some political power or influence, contributed to a certain fragmentation of Christian participation in the political and societal life. ${ }^{2}$ This system was certainly modified and adapted to the new political circumstances, when after the collapse of the Ottoman Empire, new national states were established in the Middle East, and Christians often contributed to the development of the idea of a secular nationalism, where religion would play a less important role in the political sphere. For Iraq, one could think of a certain Christian participation in the early developments of the Iraqi Communist Party ${ }^{3}$ and, in a later period, the secular Baath party. ${ }^{4}$ From a different perspective, the decision of the first government of the Iraqi Kingdom comes to mind, which expulsed the Assyrian Patriarch when he refused to content himself with a religious role without civil/political responsibilities in the newly established Iraqi State. ${ }^{5}$ Still, Christian participation in political and societal life often continued to be realized through the religious community. According to the Constitution of 1924 a number of parliamentary seats were reserved for the Christian communities. The Chaldean Patriarch Yusif Ghanima (d. 1958) was personally a member of the Senate and, in a more recent period, the dissident, old-calendarist Church of the East ${ }^{6}$ was courted for a certain time by the Saddam regime for its non-ethnic profile, which suited its policy of Arabization of the country. ${ }^{7}$

$\left.{ }^{2}\right)$ For this development, see e.g. HaJjar (1962), 265-267. For the Chaldean and Assyrian Churches, the most important Christian communities in Iraq, their recognition as millet-s and the role of the patriarchs as millet-head, see JosE PH (2000), $57,59-61$.

3) Cf. Batatu (1978), 400-450, 699-701.

4) Valognes (1994), 753-54. O’Mahony (2004b), 30-31.

5 ) The expulsion of the patriarch happened manu militari near the village of Semel, north of Dohuk, in Kurdistan and degenerated into the massacre of several thousands of Assyrian and Chaldeans Christians, cf. IsHow (2002), 199-2006.

$\left.{ }^{6}\right)$ See infra, appendix.

$\left.{ }^{7}\right)$ Jose PH (2000), 248-249. 
However, the political developments in Kurdistan, the conflict which opposed the Iraqi Kurdish leadership to the central Government in the seventies $^{8}$ and the intensification of the Arabization policy by the Saddam regime contributed to the creation of a "secular" Christian political party in Kurdistan in 1979, the Zow $\bar{a}$ Dimoqrātiyy $\bar{a}$ Atorāy $\bar{a}$ (the official Syriac name; Arabic: al-Haraka al-Dìmuqrātiyya al-Ashūriyya) or the Assyrian Democratic Movement (ADM). ${ }^{9}$ Ideologically, Zow ${ }^{e} \bar{a}$ defended the theory that the label "Ator $\bar{a} y \bar{a}$ " (Assyrian) should not be limited to one specific ecclesiastical denomination, "the Assyrian Church of the East", but rather refers to a distinct non-Arabic and non-Kurdish, Assyrian ethnic and national identity, interpreted as the continuation of the pre-Christian Assyrian civilization and shared by the five Churches of Iraq using Syriac as their literary and ecclesiastical language (the Assyrian Church of the East, its old-calendarist offspring, the Old Church of the East, the Syriac Orthodox Church and two Uniate Churches, the Chaldean Church and the Syrian Catholic Church). ${ }^{10}$ It was an attempt to overcome the traditional ecclesiastical divisions, which however continue to play a role in the political field, as will be seen below. ${ }^{11}$ This struggle for a distinct ethnic, non-Arabic identity made ADM a natural ally of the Kurds striving for the recognition of Kurdish ethnic and political rights. In 1991, with the support of the International Community, Kurdistan received a certain form of autonomy, which allowed for the creation of new political structures such as a Kurdish Regional Government and a Kurdish Assembly.

The Christian community was richly rewarded for its participation in the struggle for autonomy. No less than five seats of the new Assembly consisting of 105 seats were allotted to the Christian minority. At the elections of 1992, Zow $w^{c} \bar{a}$ won four of the five Christian seats, the remaining one went

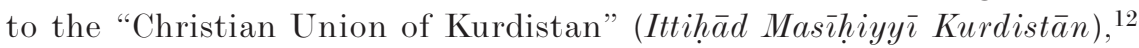
represented by Mr Sarkis Aghajan Mamendo, one of the future important

8) For a survey, see Yeldiz (2007), 15-24.

$\left.{ }^{9}\right)$ BaABA (1992).

${ }^{10}$ ) For those not familiar with the complicated ecclesiastical situation in Iraq, a brief survey of the different Churches can be found in an appendix to this article.

11) The ideology of an Assyrian ethnic identity common to all Churches using (or having used) Syriac as literary language was first formulated by the Assyrian Democratic Organisation (ADO), founded in Syria in 1957. Though mainly present in Syria and the European Diaspora, ADO is actively involved in Iraqi politics and cooperates closely with Zow $\bar{a}$. On ADO and other "Assyrian" parties/Movements, see Yonan (1978), 97-109; 129-130.

12) Cf. Yeldiz (2007), 45; McDowall (2005), 381-382. 
Christian politicians of the Kurdish region. ${ }^{13}$ Since the 100 Kurdish seats were equally divided between the rivaling Kurdish Democratic Party (KDP) of Mas' $\bar{u} d$ Barzānī (Dohuk-Arbil) and the Patriotic Union of Kurdistan (PUK) of Jalal Talabani (Sulaymaniyah), the Christian parties were able to exert a certain influence in the political arena, certainly more than could be expected on the basis of their numerical presence in Kurdistan. Zow ${ }^{e} \bar{a}$ was even offered participation in the newly formed Kurdish government, where Yonadam Yousef Kanna, one of the founders of the ADM, occupied the post of Minister of Public Works, Housing and Environment. Several initiatives were taken to promote the teaching of Modern Syriac, to publish Modern Syriac periodicals and to support Assyrian cultural societies. ${ }^{14}$ A major event was the acceptance (December 1996) - not without fierce debates - by the Kurdish Parliament of the $7^{\text {th }}$ of August, the remembrance of the massacres in Semel, as an official national holiday. According to some Assyrians, this is the implicit recognition by Kurdish leaders of the legitimacy of a form of Assyrian nationalism in Kurdish territory. Also some other Christian Feasts (Christmas, Easter, Ascension) were recognized as official holidays as well as the first of April (Kha b-Nissan), the Assyrian New Year.

In the period from 1992 to 2003 the official situation virtually remained the same: unchanged Christian representation in the National Assembly and several Assyrian ministers in the Kurdish Government. Details will be discussed in the next paragraph.

After the fall of Saddam, participation in national Iraqi politics again became an option, a choice made by the Zow ${ }^{e} \bar{a}$ leadership which moved its headquarters from the North to Baghdad.

In October 2003, the ADM (supported by the Europe-based Assyrian Democratic Organisation, ADO) took the initiative of bringing together different Christian politicians as well as representatives of the Churches in order to discuss a common name for the Christian population instead of the traditional ecclesiastical appellations. ${ }^{15}$ Such a common name had become necessary in view of the discussions on the elaboration of a new Constitution, which would contain regulations for the position of the religious and ethnic minorities of the country. Agreement was reached on the name Chaldo-Assyrians as a common designation for the Christians of different denominations. As a concession to the Syriac Orthodox and Syriac Catholics, who found it difficult to accept the term Chaldo-Assyrian, which

\footnotetext{
13) Cf. Stansfield (2003), 201-203.

14) Yacoub (1996), 83-89.

15) Cf. N. N. (2003).
} 
traditionally refers to ecclesiastical communities with whom they had been in conflict during much of their history, the official name of the language of the newly constituted Chaldo-Assyrian community would become Suryāni, Syriac, instead of Ashūri, Assyrian. The committee in charge of the preparation of the new Constitution accepted the new name, which is found back in article 53d of the Provisional Constitution (30.6.2004), which mentions the "administrative, cultural and political rights of the Chaldo-Assyrians". ${ }^{16}$

Despite this call for unity, the Christians presented themselves at the national elections for a Constituent Assembly (30. 1. 2005) with three different Christian lists: the National Rafidain List (basically the ADM), the Assyria National Assembly and the Bet-Nahrain Democratic Party. At the same time Christians were also offered places on other lists such as the Democratic Patriotic Alliance of Kurdistan, renamed Kurdistan Alliance, a coalition of mainly KDP and PUK, and the secular Iraqi National List of Ayad Allawi, eager to attract Christian votes in the Nineveh Governorate, homeland of an important Christian community (see infra). Of the Christian lists only the National Rafidain List got the minimum required number of votes and obtained one seat, which went to Yonadam Kanna, the former minister in different KRG cabinets. No less than four other Christians, representing different Christian political or cultural organizations in Kurdistan which had put themselves under the umbrella of the Kurdistan Alliance such as the Chaldean Democratic Union Party ( $G \bar{a} b \bar{a}$

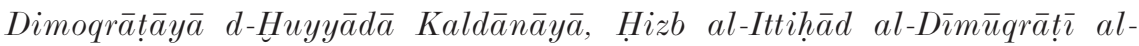
Kaldān $\bar{\imath}$ ) of Ablahad Afraim Sawa, were also elected, as well as one for the Iraqi list. Thus, the Constituent Assembly of 275 members counted 6 Christian deputies (among whom Sawa), working for three different political factions with divergent views on the relationship of the Christian minority with the region of the Kurdish regional government (KRG) and the Central government.

In October 2005, the Assembly approved the text of the new Constitution. The lack of unity among Christian parties clearly appears from article 121 which replaced article 53d of the Provisional Constitution. ${ }^{17} \mathrm{Ar}$ ticle 121 mentions the "administrative (idâriyya), political, cultural and educational rights of the various nationalities (qawmiyyāt) such as the Turkmen, Chaldeans, Assyrians and all other constituents", restoring the traditional Christian religious denominational appellations as if the

16) TEule (2008), 158-159.

17) The (Arabic) text of the Iraqi Constitution can conveniently be consulted on the website of the Iraqi Government, http://www.cabinet.iq (accessed 11.08.2010). 
"nationality" or ethnic identity of the Assyrians and Chaldeans would coincide with their ecclesiastical affiliation. ${ }^{18}$

The parliamentary elections of 15 December 2005 for the permanent Assembly of 275 members offered the same picture. ${ }^{19}$ Three Christian Lists, the National Rafidain List, in fact again only the ADM, the list of the Bet-Nahrain Democratic Party, consisting of a number of small political parties and cultural societies, and the Assyrian General Conference courted the Christian vote, whereas three non-Christian lists, such as the Kurdistan Alliance, the Iraqi National List and the Iraqi National Dialogue Front were also supported by several Christian political parties, societies or individuals. Of the Christian Coalitions it was again only the National Rafidain List which managed to reach the electoral threshold and won one seat (Yonadam Kanna). Two Christians were elected on the Kurdistan Alliance List, Fawzi Franso Toma Hariri (KDP) and Ablahad Afraim Sawa for the Chaldean Democratic Union Party, which had joined the Kurdistan Alliance. Thus, the new Parliament counted three Christian deputies, representing two ideological tendencies - close cooperation with the Kurdish region and defending the interests of the KRG on the one side or playing the card of the Central Government on the other-, which would divide the Christian political parties during much of the next years.

The Government formed on the basis of these elections had two Christian Ministers, Mrs Wijdan Mikhail Salim (Human Rights) representing the Iraqi National List ${ }^{20}$ and Fawzi Hariri ${ }^{21}$ for the KDP and the Kurdish Alliance.

For the parliamentary elections of March 2010, the Christian parties were confronted with a new situation. The emended election law of 8. 11 . 2009 increased the number of parliamentary seats from 275 to 325 , five of

18) Though Bishop Shlemon Warduni, patriarchal vicar of Emmanuel Delly, was in principle against the mentioning of nationalities in the new constitution as threatening the unity of the country, in case it would be unavoidable to insert a reference to the nationalities into the constitution, he emphasizes that all nationalities should be mentioned such as the Chaldeans, the Assyrians and the Syriacs. Apparently, for the Chaldean hierarchy, it was difficult to accept a "trans-denominational" name for the Christians of Iraq. cf. YACOUB (2008), 93.

$\left.{ }^{19}\right)$ The next paragraphs are based on interviews conducted in Arbil and Dohuk (July 2008) and on the reporting of the different elections at http://www.ankawa.com (Arabic).

${ }^{20}$ ) Till August 2007, when Wijdan Mikhail Salim became Member of Parliament for the Iraqi National List.

${ }^{21}$ ) Fawzi Hariri, son of the murdered (Christian) KDP governor of Arbil and also Minister in several KRG-KDP cabinets (see next paragraph). 
which would be reserved for the "Christian Constituent" (mukawwan) to be added to the number of seats reserved for the governorates of Baghdad, Nineveh, Kirkuk, Dohuk and Arbil. ${ }^{22}$ At the ensuing elections (7.03. 2010), no less than seven Christian Lists and parties (including two independent individuals) competed for the favour of the Christian voters, the most important being the National Rafidain List, again essentially the Assyrian Democratic Movement of Yonadam Kanna, and the Chaldean Syriac Assyrian Popular Council List (CSAPC). This Chaldean Syriac Popular Council, the creation of which will be discussed in the next paragraph, is closely related to the Kurdish KDP. Thus, with the election of three deputies for the National Rafidain List (among whom Yonadam Kanna) and two for the CSAPC-list, the two opposing ideological tendencies continued to divide the Christian Members of Parliament. ${ }^{23}$

A similar picture is given by the Governorate elections of 2005 and 2009. At the elections of 2005, ADM won one seat in the Governorate of Niniveh whereas the Assyrian National (or Patriotic) Party (al-Hizb alWatan $\bar{\imath} a l$-Ashūri), a former ally of ADM, but in recent years one of its strongest opponents, obtained one seat in the Kirkuk Governorate, but under the umbrella of the Kurdistan Alliance. At the 2009 elections (31. 1.), the Christian constituent was entitled to one reserved seat in each of the governorates of Nineveh, Baghdad and Basra. ${ }^{24}$ For Nineveh, the Christian seat went to a new party, the "Syriac Independent Gathering Movement" (Harakat Tajammue al-Suryān al-Mustaqill), which was part of the Ishtar Patriotic List, backed by the KDP, so that the pro-Kurdish tendency prevailed in the Nineveh-region, homeland of a great number of Christians (see infra), at the cost of the National Rafidain List/ADM, which lost its seat. In the Governorate of Baghdad, the Christian seat went to the Bet-Nahrain Democratic Party (Gabā Dīmōqrațāya d-Bêt-Nahrayn), a party with a long history in Kurdish national politics and affiliated with the Ishtar Patriotic List and KDP, whereas the Basra seat was won by the Chaldean Democratic Union Party, led by Ablahad Afraim Sawa, who as seen above also closely cooperates with Kurdish political factions.

22) Alwatan (2009).

23) Three Christian candidates (among whom Mikhail Salim) ran for Prime Minister al-Maliki's State of Law Coalition, but were not elected.

${ }^{24}$ ) No elections were held in the governorates of Kirkuk, Sulaymaniyah, Dohuk and Arbil, the last two of which have relatively important Christian minorities. 


\section{Christian Polities in Kurdistan}

In the previous paragraph we already briefly described the evolution of the political situation of the Christian minority in the period between 1992, when the first elections of the "independent" Kurdish region took place, and 2003, the collapse of the Saddam Hussein regime.

Despite the initial good cooperation between the different Christian and Kurdish political parties in 1992 and the results booked by Christian politicians, one of the problems that appeared difficult to solve was that of the Christian villages, houses or lands occupied by Kurds, who themselves had been expelled from their own villages, destroyed during the Anfāl campaigns of 1987-8 or during earlier raids. ${ }^{25}$ The attacks on Christian institutions and the assassination of several Assyrians (including the unresolved murder of ADM Member of Parliament Francis Shabo in 1993$)^{26}$ was also a heavy burden on Kurdish-Christian relations. Still, the cooperation continued and a number of Assyrian politicians such as Yonadam Yousef Kanna (ADM), Sarkis Aghajan Mamendo (Christian Union of Kurdistan, affiliated with KDP), Yonan Hozaya (ADM), Franso Hariri (KDP) and Yusif Hanna Yusif, known as Abu Hikmet (Independent Labour Party, affiliated with $\mathrm{KDP}^{27}$ ) were offered posts in the different KRG cabinets, either the united joint KDP-PUK cabinets between 1992 and 1996 or the KDP-cabinets between 1995 and 2006 after the troubles between KDP and PUK in $1996 .{ }^{28}$

In 2004, KDP and PUK decided to end their internal dissensions and to jointly confront the federal elections of the $31^{\text {th }}$ of January 2005 under the List of the Democratic Patriotic Alliance of Kurdistan (see supra). At the same date elections were also organized for a new regional Kurdish Assembly. In Kurdistan, four Christian factions joined the Kurdish Alliance: the ADM, the Chaldean Cultural Society, based in Arbil (Ankawa), the BetNahrain Democratic Party and the Chaldean Democratic Union. The Alliance won 104 seats of the Assembly, now consisting of 111 seats instead of 105. Five of these went to the Christian parties, two for ADM, and one for each of the other factions. The new Cabinet formed on the basis of the elec-

25) See Teule (1995), 146-147. Cf. an internal ADM document (list of Assyrian villages with a description of the kind of Kurdish aggression) (in Arabic).

${ }^{26)}$ Galletti (2010), 175-176.

27) See Stansfield (2003), 157-158; cf. United Nations High Commissioner for Refugees (2000), 30.

${ }^{28}$ ) Cf. Stansfield (2003), 147, 150, 158. For further precisions, see infra, par. 2 of this article. 
tion results (May 2006) counted three Christian ministers, Nimrod Bayto (Tourism), Georges Yusif Mansour (NGO's and Civil Society) and Sarkis Aghajan Mamendo, as seen above, one of the first Christian politicians to cooperate with the Kurds, who became Minister of Finance and Vice-Prime Minister. ${ }^{29}$

In this capacity and with Kurdish political support he was able to set up a programme for the construction (or reconstruction) of Christian villages intended to accommodate Christians expelled by Kurds from their villages in the North, but especially those Christians fleeing the violence in the areas under the control of the Federal authorities. This programme was extremely successful. About 120 villages were built or reconstructed in the region of Dohuk; several more in the neighbourhood of Zakho or in the Arbil area. At the same time, Aghajan financed the construction of churches, schools, orphanages, residences for bishops of all denominations, including a new patriarchal residence for the Chaldeans in Ankawa, ${ }^{30}$ seminaries and monasteries, for example, the restoration of the famous Mar Mattai monastery of the Syriac Orthodox. The idea was clearly to suggest that the future of Iraqi Christianity is in Kurdistan and no longer in central Iraq. The result was that since 2006 the number of Christians in the KRG-region has probably more than doubled and presently consists of more than 100.000-120.000 persons.

Another important initiative that received the active support (and the financial means) of Sarkis Aghajan was the creation of the popular Chaldean Syriac Assyrian Council (mawtbā ${ }^{c} a m m \bar{a} y \bar{a}$ Kaldāy $\bar{a}$ Soryāya

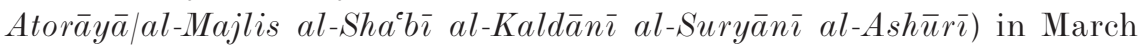
2007 in Ankawa. The objectives of the Council are among other matters the unification of the "Chaldean Syriac Assyrian" (CSA) people, promoting the Syriac language and culture and the establishment of autonomy in the "historical regions" of the CSA people. The Council, elected in 2007 and meant to represent all factions of the CSA people, consisted of 21 representatives from the Iraqi Governorates with Christian minorities (Nineveh, Dohuk, Arbil, Baghdad, Sulaymaniyah, Kirkuk and Basra). In addition,

${ }^{29}$ ) At the elections for the three governorates in the KRG-region, the Christian parties did not succeed in winning seats. However, the KDP approved the nomination of Franso Hariri as governor of Arbil (in office till 1999; cf. STAnsfield (2003), 231; he was murdered in 2001) and of Georgis Shlemon as Deputy Governor for Dohuk. No governorate elections took place in the KRG region in 2009.

${ }^{30}$ ) In Ankawa, preparations are even being made for the construction of a residence for the Patriarch of the Church of the East, now residing in Chicago. 
ten seats were reserved for CSA political parties or cultural institutions, ${ }^{31}$ five seats for the members of the preparatory committee of the conference and another five for the diaspora.

Despite the enormous response by different layers of the Christian Iraki population - the first meeting in March 2007 was attended by no less than 1.200 persons - the initiative failed to bring unity, since the important ADM refused to participate on account of divergent views on the issue of autonomy (see next paragraph). As a matter of fact, the Council gradually developed into a political party itself instead of an umbrella organization and participated, as seen above, in the federal legislative elections of 2009 , with the result that a number of parties or societies mostly with an outspoken Chaldean profile such as the Chaldean National Council decided to go their own way and left the majlis.

For the parliamentary elections of the $25^{\text {th }}$ of July 2009 , five seats (of 111 ) were explicitly reserved for the Christian minority, thus legalizing the situation which de facto existed already in the previous Assembly of 2006. In addition, one seat was reserved for the Armenians, who are present in several Kurdish towns such as Zakho or villages (Avzrog Armani and the recently rebuilt village of Hawrezk near Dohuk). Initially, no less than eight different Assyrian parties signed up to participate. Eventually the Bet-Nahrain Democratic Party withdrew. The small Assyrian National

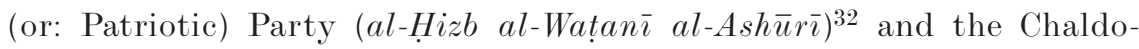
Ashur Communist Party decided to ran jointly under the so-called Chaldean Syriac Assyrian Autonomy List. The Chaldean National Council (al-

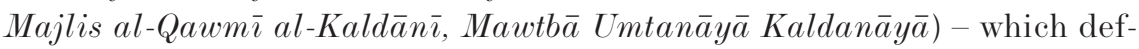
ends a distinct Chaldean national or ethnic identity and opposes the in their eyes artificial CSA appellation defended by the Popular CSA Council - formed a new Chaldean United List together with the Chaldean Democratic Union. The two other Lists participating in the elections were the CSA Popular Council List and the National Rafidain List (ADM). ${ }^{33}$ As was to be expected, the winning seats went to the CSA Popular Council List (3 seats) and the National Rafidain List-ADM (2 seats). Together with the seat reserved for the Armenians they make a Christian parliamentary fac-

31) The most important of these were Bet-Nahrain National Union, BetNahrain Democratic Party, The Chaldean Democratic Minbar, The Syriac Independent Gathering Movement, the Chaldean National Council, the Assyrian Patriotic Party and the Chaldean Cultural Society.

$\left.{ }^{32}\right)$ Though this party was not elected in the 2005 Kurdish Assembly its leader, Nimrud Bayto was appointed minister of tourism in the KRG from 2006-2009.

${ }^{33}$ ) Cf. Assyrian International News Agency (2009). 
tion of 6 members. The new Government formed on the basis of the election results had only one Christian minister (Anwar Jabali Sabo, ADM, Minister of Transport and Communications).

From the above it is clear that the same issue which divides the Christian politicians on the federal level (relation to Kurdistan and the KRG government) also plays a role in regional Kurdish Christian politics. In addition, it has to be mentioned that in certain Chaldean circles there is some mistrust concerning the true intentions of the KDP/Kurdistan Alliance who they fear might use Christian votes to strengthen only their own position on the federal level. In this respect, they point to the long history of enmity between Kurds and Christians, even in the recent past, and the fact that the issue of Christian lands confiscated by the Kurds (see supra) has not yet been solved. It may be true that many Chaldeans have their origins in villages situated in Kurdistan and recognize that the housing project of Sarkis Aghajan has been an answer to the situation of insecurity in Central Iraq. However, for many of them Arabic has become their first language due to their long presence in Baghdad or other Arabic cities. They have no knowledge of the Kurdish languages ${ }^{34}$ and, because of the uncertainties of the Kurdish project, do not wish to integrate into the Kurdish society. Finally, some Chaldeans reject the ideology of the common CSA identity defended by both the Popular Council and the ADM as artificial and not reflecting their identity which they feel is distinct from an Assyrian identity, ecclesiastically, but also ethnically. ${ }^{35}$

34) The answer of the Popular Council would be that for these Chaldeans it is perfectly possible to go schools in Kurdistan were Arabic (or even Sureth) is the main language of instruction. In this respect, provisions have been made exactly for Chaldeans who have only recently settled in Kurdistan.

${ }^{35}$ ) In this sense, one has to understand the intervention by the Chaldean Patriarch Emmanuel Delly asking President Massoud Barzani not to accept the composed unified name of CSA proposed by the Popular Council for the Constitution of Kurdistan (http://www.iraqichristians.info/English/Patriarch_EmmanuelDelly_rejects _FakeName_24_8_2009.htm, accessed 18.8.2010). Article 5 of the revised draft of the Kurdistan Constitution now mentions as non-Kurdish nationalities: the Turkmen, the Chaldeans, the Assyrians, the Armenians and the Arabs (http://www. alsabaah.com/paper.php? source=akbar\&mlf=interpage $\&$ sid $=86172$. Arabic text, accessed 18.8.2010), mutatis mutandis comparable to article 121 of the Federal Constitution. 


\section{The discussion on autonomy}

One of the reasons for the ADM to part ways with the CSA Popular Council is its different interpretation of the idea of autonomy for the Christian minority, one of the main objectives of the Council's programme. ${ }^{36}$

As seen in the second paragraph, Article 121 of the Federal Constitution speaks of the "administrative (idāriyya), political, cultural and educational rights of the various nationalities (qawmiyyāt) such as the Turkmen, Chaldeans, Assyrians and all other constituents". According to the interpretation of ADM, this article allows for a form of self-administration (idāra dhātiyya) as a first step to a possibly more complete selfgovernance or autonomy in a later stage. Its implementation in the Plain of Nineveh, homeland (Atra) of an important minority of Christians of different denominations, especially the Chaldeans, the Syriac Orthodox and the Syriac Catholics, ${ }^{37}$ is one of its core objectives. Various Christian organizations, both in the diaspora as well as in Iraq itself, go a step further and want full autonomy or self-governance (hukm $d h \bar{a} t \bar{\imath})$. Sarkis Aghajan is one of the most outspoken representatives of this idea. His vision can be found in a brochure, ${ }^{38}$ in which he states that, unlike in the case of local self-administration, autonomy implies the creation of a Parliament and a Council of Ministers with legislative or executive powers; the autonomous region should have full authority, not only in personal matters, but also in issues of land and soil, which in the case of self-administration remain under the authority of the competent federal Authority. Autonomy also implies the right to a fair part of the national budget, not just in the form of subsidies, as well as their own police and security forces. In personal matters, the Christians living outside the autonomous region would also fall under its authority. The CSA Popular Council finds support for Aghajan's ideas in Section $V$ of the Constitution, where the articles 112-117 offer the possibility to form new regions with the right to exercise executive, legislative and judicial powers. ${ }^{39}$

A second point of divergence between ADM and CSA Popular Council is the relationship of the envisaged Atra with the Kurdish region. Officially, the CSA Popular Council holds that it will be left to the inhabitants of the

\footnotetext{
${ }^{36}$ ) Teule (2009), 53-55.

37) For a description of the most important Christian villages, see Mérigoux (2000), 213-278.

${ }^{38)}$ Kako, Interview with Mr Sarkis Aghajan on the Issue of Autonomy (Hukm dhàti) for our Chaldean-Syrian-Assyrian People (in Arabic), [Arbil], 2007.

$\left.{ }^{39}\right)$ Cf. Yacoub (2010), 153.
} 
Nineveh Plain themselves to decide about a future relationship with the Kurdish region. In reality, the politicians of the Council think of strong institutional bonds with Kurdistan ${ }^{40}$ and even express the wish that the Atra should not be limited to the Plain of Nineveh, but should also include a number of Assyrian villages within Kurdistan itself (e. g. the region of Berwari Bala along the Turkish border, the region around Dohuk, ...). ${ }^{41}$ For this reason, the Popular Council multiplies its efforts to subsidize housing projects, cultural and ecclesiastical institutions etc. in the Plain of Nineveh, officially belonging to the Governorate of Nineveh, outside the KRG-region, comparable to its policy in Kurdistan itself. In many cases, one has to recognize that the Council fills the vacuum left by the absence of initiatives by (or possibilities of) the local authorities, also in matters of security. The results of the last Governorate Elections for the Governorate of Nineveh, where the one seat reserved for the Christian constituent went to the KDPbacked Syriac Independent Gathering Movement/Ishtar Slate at the cost of the National Rafidain List/ADM which lost its seat (see supra, par. 2), suggest that the population in the Plain of Nineveh is increasingly in favour of the Popular Council's policy. However, several institutions, among which the Chaldean Democratic Union and ADM, denounce the pressure exerted by members of the Popular Council on persons who had received allowances or admittance to its housing programmes, etc. ${ }^{42}$ Especially the people of the southern parts of the Plain of Nineveh (Bakhdida and surroundings) seem to be more in favour of a form of autonomy within the Federal State.

Even the concept of autonomy itself is heavily contested. The most outspoken adversary of this idea is probably the Chaldean Archbishop of Kirkuk, Mgr Louis Sako. On several occasions he has pointed to the recent and not so recent history of Iraqi Christianity, characterized by cooperation and living together with Muslim Arabs ${ }^{43}$ as well as to the prominent role

$\left.{ }^{40}\right)$ Cf. The Status of Christians in the Kurdistan Region in Iraq. A short Report by the Kurdistan Regional Government UK Representation. December 2009: http:// www.krg.org/uploads/documents/Status_Christians_Kurdistan_Region_ Dec_09_2009_12_22_h16m26s\&6.pdf (accessed 18.8.2010)

$\left.{ }^{41}\right)$ The Council finds support for this possibility in article 35 of the Kurdish draft Constitution, guaranteeing "national, cultural and administrative rights for the non-Kurdish nationalities".

${ }^{42}$ ) Cf. Assyrian Council of Europe (2009; Unrepresented Nations and Peoples Organization u. Assyrian Council of Europe (2009).

43) This is also the background of L. SAKo's recent book, Christian-Muslim Dialogue. Theological Approaches in the Arabic language in the Abbasid Period, Kirkuk, 2009 (in Arabic). 
the Chaldean Church was able to play within the Iraqi society at large. In his opinion, the Atra risks becoming a sort of ghetto and reducing Christianity to an ethnic community, preventing Christians witnessing to their mission in a meaningful way on the national level. ${ }^{44}$

\section{Concluding Remarks}

The recent years have seen the multiplication of Iraqi Christian political parties and cultural societies, mostly operating distinctly from the Churches, which traditionally played the role of representing the Christian community on the national forum. This development started with the creation of an autonomous Kurdistan in 1992, but intensified after the collapse of the Saddam regime in 2003. This does not mean that the role of the Churches is only limited to religious matters. They actively participate in the debate on ethnic identity. This is shown by the efforts of some members of the Chaldean hierarchy to oppose the common Chaldean Syrian Assyrian appellation defended by the Popular Council. It can also be seen in the Chaldean opposition to the Chaldo-Assyrian compound-name proposed by Zow ${ }^{e} \bar{a}$ during its discussions on the place of the Christians in the new Iraqi constitution. Members of the hierarchies of both the Assyrian and Chaldean Churches likewise express themselves on the issue of autonomy and the creation of a Christian Atra in the plain of Nineveh.

The main division between the Christian political parties is about two related issues:

1. The question of "autonomy" of the envisaged Atra: should it imply self-administration, limited to personal matters, as a first step to more encompassing forms of autonomy, which is the position defended by ADM, or should it be self-governance with far-reaching political powers for the authorities of the future Atra, as defended by CSA Popular Council?

2. Should the "autonomous" Atra, situated in the Plain of Nineveh have institutional bonds with the KRG administration or even be incorporated into the KRG-region? This is the unambiguous option of the CSA Popular Council as well as of the Assyrian Autonomy List, but categorically rejected by ADM and its allies.

$\left.{ }^{44}\right)$ See, for instance, the brief article by Mgr Louis Sako, Chaldean Archbishop of Kirkuk, 15.6.2007: Sako (2007). 


\section{Appendix: The Christian Communities of Iraq ${ }^{45}$}

The most autochthonous community is the so-called "Assyrian Church of the East", which has a long history in Iraq. Its beginnings in Mesopotamia - North and Central Iraq - go back to the second century, thus long before the coming of Islam. In the Abbasid period, the centre of their community was in Baghdad and their leaders were the privileged interlocutors of the Islamic authorities; their contribution to the development of Islamic theology and an Islamic culture and civilization in general is widely acknowledged. ${ }^{46}$ Due to the vicissitudes of history - especially the grim period following the incursions of Timur -, of which Muslims, too, were the victims - these "Assyrians" left central Iraq, withdrew to the region that today we call Kurdistan, were marginalized and organized themselves along tribal lines. This meant that, among other things, the functions of ecclesiastical and tribal leader merged into each other, a method of organization that would be even more institutionalized in the Ottoman Empire (1517-1922), with its millet-system. (How the Assyrians fitted into this system still has to be studied in greater detail). ${ }^{47}$ After the first World-War and the massacres of large groups of Christians in Eastern Anatolia, the remainder of the Assyrians fled to central Iraq, where they had to stay - or wanted to stay - for various reasons, one of them being the promises made by the British for some form of autonomy or independence. However, when, in the thirties of the last century, the new independent Kingdom of Iraq was founded, their leader was not prepared to give up the secular role he had played in the traditional society of the Middle East and to restrict his function to that of a religious leader, which was offered to him by the newly formed government. For this reason, he and many of his followers were expelled from the country - this fact is still remembered today by the members of the community as "martyrs' day" (on the $7^{\text {th }}$ of August) on account of the bloody way this expulsion was carried out - and eventually settled in the United States. ${ }^{48}$

The Assyrian Church has a strong consciousness of being an ethnic community. Most of its members express themselves in Sureth, a neo-Aramaic language, and, during the liturgical services, it is a point of honour exclusively to use the old Syriac language (a form of Aramaic) or also

$45)$ This appendix is, with a few adaptations, taken from TeULE (2009), 47-50.

$\left.{ }^{46}\right)$ See e.g. the work of Sako (2009).

${ }^{47}$ ) Jose PH (2000), 59-61 cf. supra, par. 1.

${ }^{48}$ ) For general surveys of the history of this community, see Le Coz (1995); Teule (2008). 
Sureth, but hardly ever Arabic. Assyrian - in Sureth: Atorāyā-traditionally designates the land of Ator or the region of Mosul. According to some modern and relatively recent interpretations, it has received the meaning of "being in continuity with the old pre-Christian civilization of Assyria", of which the Church of the East would be the Christian continuation. ${ }^{49}$ Accordingly, their language was also called "Assyrian" (see infra). On account of this outspoken ethnic position (an Assyrian, not Arabic, identity), a number of priests fell victim to the politics of Saddam Hussein (Arabization) in the eighties of the last century. ${ }^{50}$

In 1968, a rival Assyrian Church was founded in Baghdad. Officially, the main reason for this step was opposition to certain liturgical reforms decreed by the Patriarch in Chicago (introduction of the Gregorian calendar). Underlying reasons were traditional tribal dissensions. ${ }^{51}$ This new Assyrian Church received the support of President Ahmad Hasan al-Bakr and the Iraqi government and later the Saddam regime. Understandably, therefore, it did not have the label Assyrian in its official name.

In the course of the $17^{\text {th }}$ to $19^{\text {th }}$ centuries, the Assyrians were the object of intensive missionary activities on the part of the Protestants and the Catholics. The presence of Catholics eventually led important Assyrian groups to enter into communion with Rome and brought about the establishment of a new ecclesiastical community, called the Chaldean Church. The Chaldeans accepted the authority of the Pope of Rome and the dogmatic specificities of the Roman Catholic Church but were allowed to keep a number of "oriental features", characteristic of the Church of the East, but unknown in the mainstream Roman Catholic Church, such as a synodical structure, the traditional East Syrian liturgy and spirituality and its own Canon Law. Numerically, it is today the most important Christian community of the country ( $80 \%$ of the total Christian population). Ethnically, the Chaldean Church has the same distinct identity as the Church of the East, from which it split. ${ }^{52}$ Many of its members speak Sureth, whereas Syriac is their cultural and liturgical language, or at least their language of reference. However, there is one important difference. Since the creation of the state of Iraq, the Chaldeans, unlike the majority of the members of the

${ }^{49}$ ) For the sensitive problem of the name Assyrian and the question of ethnic identity, see CoAkley (1992), 147-148; Heinrichs (1993); Jose PH (2000), 17-19.

${ }^{50}$ ) Teule (1995), esp. 143.

$\left.{ }^{51}\right)$ Proche Orient Chrétien 18 (1968), pp. 388-389; 19 (1969), 278-280, 393-394.

${ }^{52}$ ) Some Chaldeans hold that their ethnic identity is different from that of the Assyrians. This is e.g. the position of the Chaldean National Council (cf. supra, par. 3 ) and of e. g. the Chaldean Bishop Sarhad Jammo (California). 
Church of the East, have added an Arabic layer to their original ethnic identity. This was basically the result of the fact that, after World War II, the majority of their members had moved to central Iraq, Baghdad and of the ensuing awareness that many Chaldeans had gradually lost the knowledge of their native language. This assumed Arabic identity earned them the sympathy, not only of the leadership of the independent Iraqi State, but also, in later times, of the Saddam regime, and partly explains the privileged position the Chaldean Church could occupy within the Iraq of Saddam Hussein. ${ }^{53}$

The third (or fourth) indigenous community is that of the Syriac Orthodox.54 Though dogmatically, and hence ecclesiastically or denominationally, entirely different from the Assyrians - in the past, both communities struggled intensively with each other on dogmatic issues ${ }^{55}-$, both communities are the same from an ethnic point of view: they share the same Syriac language, which is also used by the Syriac Orthodox during their liturgy and in their literature; the latter also speak Sureth in daily life. However, their perception of ethnicity is different from that of the Assyrians. Whereas the Assyrians, as we have seen, put forward the continuity of their language and culture with the pre-Christian Assyrians, many Syriac Orthodox rather tend to emphasize that their language is Aramaic and that they are Arameans. In the modern discussions on their identity in Iraq, they designate themselves as Suryān, their language as Suryânî.

The fourth community consists of a group of Syriac Orthodox who, in imitation of the Chaldeans, entered into communion with Rome, but maintained their former liturgical rites and, of course their ethnic particularities, which are the same as the previous community. ${ }^{56}$

These are the four or five autochthonous Churches, which, however, do not cover the whole modern Christian population of Iraq. There is a small Armenian Orthodox and Armenian Catholic community, especially in Baghdad and, until recently, in Mosul. Their presence in Iraq is relatively recent and goes back to different migration movements in the Ottoman period and, more recently, to the aftermath of the First World War, when a number of Armenians from Eastern Anatolia settled in Northern Iraq. Apart from the latter group, which expresses itself mainly in Badini, the

53) O’Mahony (2004a).

54) A general introduction: SÉLIs (1988).

${ }^{55}$ ) Cf. For a historical survey and analysis of recent developments, see BRock (2004).

${ }^{56)}$ O’Mahony (2006), 515-519. 
Kurmanji language of that region, ${ }^{57}$ the Armenians have strong ethnic feelings of belonging to the Armenian community and express themselves in Armenian. Since the $18^{\text {th }}$ century, there is a small Latin (Roman-Catholic) community, mostly in Baghdad. Their members speak Arabic (or are foreigners). ${ }^{58}$ The Anglican and the traditional Protestant Churches are represented in Baghdad, whereas, since the collapse of the Saddam regime, American protestant fundamentalist missionaries are active both in Kurdistan and in central Iraq.

\section{Bibliography}

Assyrian Council of Europe (2009), "Violations and other threats against Assyrians during pre-election Period in the Nineveh-plain", http://www.assyriacouncil. eu/3.html (accessed 10.2.2009).

Audo (2008): Antoine Audo, "Les Chrétiens d'Iraq", Etudes. Revue de culture contemporaine 408/2, 209-218.

Batatu (1978): Hanna Batatu, The Old Social Classes and the Revolutionary Movements of Iraq, Princeton.

Brock (2004): Sebastian Brock, "The Syriac Churches in ecumenical dialogue on Christology", in: Anthony O'Mahony (Ed.), Eastern Christianity. Studies in Modern History, Religion and Politics, London, 44-65.

CoAkley (1992): John Coakley, The Church of the East and the Church of England. A History of the Archbishop of Canterbury's Mission, Oxford.

Filoni (2009): Fernando Filoni, L'Église dans la terre d'Abraham. Du diocese de Babylone des Latins à la nonciature apostolique en Iraq, Paris.

Galletti (2010): Mirella Galletti, Le Kurdistan et ses chrétiens, Paris (New Edition by Mirella Galletti (2003), Cristiani del Kurdistan, Rom).

HajJar (1962): Joseph Hajjar, Les chrétiens uniates du Proche-Orient, Paris.

HeAly (2010): John Healy, "The Church across the Border" The Church of the East and its Chaldean Branch, in: A. O'Mahony and E. Loosley (Eds.), Eastern Christianity in the Modern Middle East, Abindon, 2010, pp. 43-55.

Heinrichs (1993): Wolfhart Heinrichs, "The Modern Assyrians-Name and Nation", in: Riccardo Contini (Ed.), Semitica. Serta philologica Constantino Tsereteli dicata, Torino, 99-114.

57) Due to recent (since 2006-7) migration of Armenians from Central Iraq to the rebuilt Armenian village of Hawrezk (near Dohuk), Armenian is beginning to be used in Kurdistan as well (see supra, par. 2). Sarkis Aghajan has also subsidized the construction of an Armenian village near Karamlish in the Nineveh Plain.

$\left.{ }^{58}\right)$ For the history of the Latin Community in Iraq, see Filoni (2009). 
Jose PH (2000): John Joseph, The Modern Assyrians of the Middle East. Encounters with Western Christian Missions, Archeologists \& Colonial Power, Leiden.

Le Coz (1995): Raymond Le Coz, Histoire de l'Eglise d'Orient. Chrétiens d'Irak, d'Iran et de Turquie, Paris.

Kako, W. Interview with Mr Sarkis Aghajan on the Issue of Autonomy (Hukm dhàtī) for our Chaldean-Syrian-Assyrian People (in Arabic), [Arbil], 2007.

Merigoux (2000): Jean-Marie Mérigoux, Va à Ninive! Un dialogue avec l'Irak, Paris.

O'Mahony (2004a): Anthony O'Mahoney, The Chaldean Catholic Church: the Politics of Church-State relations in Modern Iraq", Heytrop Journal XLV, $435-450$.

O’Mahony (2004b): Anthony O'Mahoney, "Eastern Christianity in Modern Iraq", in: Anthony O'Mahony (Ed.), Eastern Christianity. Studies in Modern History, Religion and Politics, 11-43.

O’Mahony (2006): Anthony O'Mahoney, "Syriac Christianity in the Modern Middle East", in: Michael Angold (Ed.), Eastern Christianity, The Cambridge History of Christianity 5, Cambridge, 511-535.

Proche Orient chrétien 18 (1968), pp. 388-389; 19 (1969), 278-280, 393-394

Rassam (2006): Suha Rassam, Christianity in Iraq, Leominster.

Sako (2007), Louis Sako, "Niniveh Plains project to destroy dialogue, only path for peace", www.asianews.it.

SAKo (2009): Louis Sako, Christian-Muslim Dialogue. Theological Approaches in the Arabic language in the Abbasid Period, Kirkuk.

SELIS (1988): Claude Sélis, Les syriens orthodoxes et catholiques, Turnhout.

Stansfield (2003): Gareth Stansfield, Iraqi Kurdistan. Political Development and emergent Democracy.

Suermann (2006): Harald Suermann, "The History of Christianity in Iraq of the $20^{\text {th }}$ and $21^{\text {th }}$ Century", The Harp XX, 171-194.

Suermann (2010): Harald Suermann, "Irak" in Harald Suermann (Ed.), Kirche und Katholizismus seit 1945, Naher Osten und Nordafrika 7, Paderborn, $53-85$.

Teule (1995): Herman Teule, "Noord Irak", Het Christelijk Oosten 47, 140-147.

Teule (2008): Herman Teule, Les Assyro-chaldéens, Turnhout.

Teule (2009): Herman Teule, "The Christian Minorities in Iraq. The Question of Religious and Ethnic Identity", in: Christiane Timmerman, Johan Leman, Hannelore Roos u. Barbara Segaert (Eds.), In-Between Spaces. Christian and Muslim Minorities in Transition in Europe and the Middle East, Gods Humans and Religions 18, Brussels, 45-60.

Valognes (1994): Jean-Pierre Valognes, Vie et mort des Chrétiens d'Orient. Des origins à nos jours, Paris.

Winkle R (2009): Dietmar Winkler, „East Syriac Christianity in Iraq. A Glance at History from the First World War until Today", in: Dietmar Winkler u. Li Tang (Eds.), Hidden Treasures and Intercultural Encounters. Studies on East Syriac Christianity in China and Central Asia, Wien-Berlin, 321-334. 
Yacoub (2008): Joseph Yacoub, "La marginalisation des chrétiens d'Iraq", Confluences Méditerranée 66 83-98.

YAcouB (2010): Joseph Yacoub, "Du traitement des minorités en Irak: le statut des chrétiens", Etudes interculturelles 3, 139-154.

\section{Internet resources:}

Alwatan (2009): Donia Alwatan, "Blog entry 10. 11. 2009", http://www.alwatanvoice. com/arabic/news/2009/11/10/143617.html (accessed 12.08.2010).

Assyrian International News Agency (2009), "Kurdish Election Lists", http:// www.aina.org/news/20090630201850.htm (accessed 18.8.2010). http://www. alsabaah.com/paper.php? source=akbar\&mlf $=$ interpage\&sid $=86172$.

Unrepresented Nations and Peoples Organization u. Assyrian Council of Europe (2009), "Election-Observation Mission. Nineveh-Plain Iraq", http://www. assyriacouncil.eu/3.html (accessed 10.2.2009).

"The Final Statement of the Chaldean Syriac Assyrian General Conference" (2003), http://en.ado-world.org/news/assyrian-news/article/th-final-statement-of-the (accessed 1.8.2010).

Popular Council for the Constitution of Kurdistan, http://www.iraqichristians. info/English/Patriarch_EmmanuelDelly_rejects_FakeName_24_8_2009.htm, (accessed 18.8.2010).

The Status of Christians in the Kurdistan Region in Iraq. A short Report by the Kurdistan Regional Government UK Representation. December 2009 http://www.krg.org/uploads/documents/Status_Christians_Kurdistan_Region _Dec_09_2009_12_22_h16m26s\&6.pdg (accessed 18.8.2010)

"Patriarch Calls For Assyrian Administrative Unit In North Iraq" (2008), http://www.middleeastinfo.org/forum/index.php? showtopic $=15768$.

United Nations High Commissioner for Refugees (2000), "Official general report on Northern Iraq. April 2000", http://www.unhcr.org/refworld/pdfid/6700d7d2.pdf. 